\title{
An exergetic performance assessment of three different food driers
}

\author{
A Hepbasli ${ }^{1 *}$, Z Erbay $^{2}$, N Colak $^{3}$, E Hancioglu ${ }^{4}$, and F Icier ${ }^{2}$ \\ ${ }^{1}$ Department of Mechanical Engineering, Faculty of Engineering, Ege University, Izmir, Turkey \\ ${ }^{2}$ Department of Food Engineering, Faculty of Engineering, Ege University, Izmir, Turkey \\ ${ }^{3}$ Department of Food Engineering, Faculty of Engineering, Pamukkale University, Denizli, Turkey \\ ${ }^{4}$ Geothermal Energy Research and Application Center, Izmir Institute of Technology, Izmir, Turkey
}

The manuscript was received on 21 April 2009 and was accepted after revision for publication on 27 July 2009.

DOI: 10.1243/09576509JPE802

\begin{abstract}
In this study, plum slices were dried in three different driers (tray, fluid bed, and heat pump (HP) driers). Drying experiments were carried out at an air temperature range of $45-55^{\circ} \mathrm{C}$ with an air velocity of $1.5 \mathrm{~m} / \mathrm{s}$. The performance of the driers along with their main components was evaluated and compared by using the exergy analysis method. The most important component for improving the system efficiency was determined to be the fan-heater combination for both the tray and fluid bed driers, and the motor-compressor assembly for the HP drier. The exergy loss and flow diagram (the so-called Grassmann diagram) of the driers was also presented to give quantitative information regarding the proportion of the exergy input dissipated in the various system components. Effects of the drying air temperature on the performance of the drying process were discussed. The highest exergetic efficiency values were obtained to range from 72.72 to 75.66 per cent for the HP drier, followed by the tray and fluid bed driers varying between 37.94 and 39.46 per cent, and between 22.83 and 24.07 per cent, respectively.
\end{abstract}

Keywords: drying, exergy analysis, fluid bed drier, heat pump drier, performance evaluation, tray drier

\section{INTRODUCTION}

Drying is one of the oldest unit operations, and widespread in various industries recently. In food industry, foods are dried starting from their natural form (vegetables, fruits, grains, spices, milk) or after handling (e.g. instant coffee, soup mixes, whey). The production of a processed food may involve more than one drying process at different stages and in some cases pre-treatment of food is necessary before drying. The main purpose of food drying is to preserve and extend the shelf life of the product. In addition to this, drying in food industry is used to obtain the desired physical form (e.g. powder, flakes, granules); to obtain the desired colour, flavour, or texture; to reduce the volume or weight for transportation; and to produce new products that would not otherwise

\footnotetext{
* Corresponding author: Department of Mechanical Engineering, Ege University, Izmir 35100, Turkey.

email:arif.hepbasli@ege.edu.tr
}

be feasible $[\mathbf{1}, \mathbf{2}]$. The methods of drying are diversified with the purpose of the process. There are more than 200 types of dryers [1]. For every dryer, the process conditions, such as drying chamber temperature, pressure, air velocity (if the carrier gas is air), relative humidity, and the product retention time, have to be determined according to feed, product, purpose, and method. On the other hand, drying is an energyintensive process, while its energy consumption value varies between 10 and 15 per cent of the total energy consumption in all industries in developed countries $[\mathbf{1}, \mathbf{3}]$. Therefore, optimization of the drying processes and systems is important with regard to the energetic efficiencies.

During the past few decades, thermodynamic analyses, particularly exergy analyses, have appeared to be an essential tool for system design, analyses, and optimization of thermal systems [4]. Exergy analysis is a very useful tool that can be successfully used in the design and the simulation of energy systems, and provides necessary information to choose the appropriate component design and operation procedure. This 
information is much more effective in determining the plant and operation costs, the energy conservation, the fuel versatility, and the pollution. By using exergy analysis method, magnitudes and locations of exergy destructions (irreversibilities) in the whole system can be identified, while potential for energy efficiency improvements can be introduced [5]. The mathematical models for exergy analysis of drying of biological products have been developed $[4,6-8]$. The energy analysis method has been widely used for evaluating the performance of food systems (especially food dryers), while studies on exergy analysis were relatively few in number [9-20].

In this study, three different drying systems were used for drying plums slices, while the performance assessment for each component of these systems and the whole systems was done using the exergy analysis method. The effect of drying temperature on the efficiencies of the systems and components was studied in terms of exergetic efficiency, improvement potential rate, and exergetic factor. Suggestions towards improving the efficiencies of the drying systems were made. This work also aims at revealing the insights that will aid investigators, designers, and operators of such systems.

\section{MATERIALS AND METHODS}

\subsection{Plums}

Freshly harvested plums (Prunus domestica Insititia) were purchased from a local market in Izmir, Turkey. The purchased plums were cleaned and dipped into 1 per cent $\mathrm{NaOH}$ solution for $15 \mathrm{~s}$ [21, 22]. Plums were then washed with water and after removing excess water from the surface of plums with a filter paper, they were sliced uniformly (average thickness: $4.0 \pm$ $0.5 \mathrm{~mm}$ ), while the purchased plums were processed within $24 \mathrm{~h}$.

The moisture content of the plums was determined by using the vacuum oven method [23]. Experiments were triplicated. The moisture content of the fresh and dried plums was determined to be 84.49 per cent \pm 1.10 and 15.70 per cent \pm 2.56 (wet basis), respectively.

\subsection{Experimental set-up}

Plums were dried in three different drying systems, namely (a) a tray drier, (b) a fluid bed drier, and (c) a heat pump (HP) drier.

A laboratory-type tray drier (Armfield UOP8, Hampshire, UK) was used [24] and its drying air velocity was regulated by an axial flow fan and fan speed control unit. The air was heated with an electric $3000-\mathrm{W}$ heater placed inside the duct, and air temperature was controlled by a heater power control unit. Drying compartment dimensions were $0.3 \times 0.3 \times 0.4 \mathrm{~m}$. The drier included four sample trays.

A laboratory-type fluid bed drier (Sherwood Scientific, Cambridge, UK) was used [25]. In this drier, air was drawn through a mesh filter in the base of the cabinet and blown by a centrifugal fan over a $2 \mathrm{~kW}$ finned electrical heater and through a stainless-steel filter gauze before being delivered to the distributor gauze at the base of the drier body. This distributed the air uniformly to the bed and also supported it. The air blower was controlled by a thyristor circuit to give a smooth vibration over a wide range of motor speeds, giving fine control of the drying temperature. The tub unit was locked into the position on the cabinet top by a simple bayonet fitting. A filter bag was employed to retain any stray particles of the sample being fluidized while allowing the passage of exit gases.

A pilot-scale HP conveyor dryer, which was designed and constructed in the Department of Mechanical Engineering, Faculty of Engineering, Ege University, Izmir, Turkey, was used in this study [19]. The drying system consisted of two main parts: (a) heat pump (HP) and (b) drying chamber. The air was heated by an HP system that included a scroll compressor, two condensers (internal and external ones), an expansion valve, an evaporator, and a heat recovery unit (HRU). The air temperature was controlled by a control unit. R407C was used as refrigerant in the HP system. The drying air velocity was regulated by a fan and its speed control unit, and the drying air was recycled. Drying compartment dimensions were $3.0 \times 1.0 \times 1.0 \mathrm{~m}$. Plums were moved by a conveyor band system driven by a motor.

\subsection{Drying procedure and measurements}

Before starting drying processes, the system was run for at least $1 \mathrm{~h}$ to obtain steady-state conditions. Plum slices were spread onto as a thin layer. Drying experiments were carried out at a drying air temperature range of 45,50 , and $55^{\circ} \mathrm{C}$ with a drying air velocity of $1.5 \mathrm{~m} / \mathrm{s}$. Drying procedure was developed until the final moisture content of plums. Humidities, temperatures, and velocities were measured in the drying chamber with robust humidity probes (Testo, 0636.2140, Freiburg, Germany), vane/temperature probes (Testo, 0635.9540, Freiburg, Germany), professional telescopic handle for plug-in vane probes (Testo, 0430.0941, Freiburg, Germany), respectively. Measurements of drying air temperature, velocity, and relative humidity were recorded at every $5 \mathrm{~min}$. An infrared thermometer (Testo 552-T2, Freiburg, Germany) and a surface thermometer (METEX ME-32, Seoul, South Korea) were used to measure the surface temperatures of the product and drying chamber walls, respectively. A digital balance (Scaltec SBA 61 , Goettingen, Germany) was used to measure the 
weight loss of sample during drying experiments. The ambient temperature and the relative humidity were also measured and recorded. Pressures and temperatures of the refrigerant were measured with pressure probes (Testo, low/high-pressure probes, 0638.01941) and surface temperature probes (Testo, temperature probes, 0628.0019), respectively. All measured values were observed and recorded with a multi-function instrument (Testo 350-XL/454, Control unit, Freiburg, Germany) and loggers.

\subsection{Experimental uncertainty}

Uncertainty analysis is needed to prove the accuracy of the experiments. Errors and uncertainties in the experiments can arise from the instrument selection, condition, calibration, environment, observation and reading, and test planning [26]. In the present study, temperatures, air velocities, relative humidities, mass losses, and pressures were measured with appropriate instruments explained above, and total uncertainties for all these parameters were calculated individually. The accuracy of temperature-measuring equipments was $\pm 0.2^{\circ} \mathrm{C}$, while reading errors for temperature measurements were assumed as $\pm 0.1^{\circ} \mathrm{C}$. The accuracy of the digital balance used in determination of the moisture quantity of the sample was $\pm 0.0005 \mathrm{~g}$ and reading errors were assumed as $\pm 0.0001 \mathrm{~g}$. The accuracy of the velocity probes used in the air velocity measurements was $\pm 0.2 \mathrm{~m} / \mathrm{s}$ and the error coming from the flow disorder was assumed as $\pm 0.05 \mathrm{~m} / \mathrm{s}$. The accuracy of the relative humidity probes was \pm 2 per cent $\mathrm{RH}$ and reading errors were assumed as $\pm 0.1 \mathrm{RH}$. Furthermore, the pressure and temperature of the refrigerant were measured with the pressure and surface measurement probes and their accuracies were \pm 1.0 per cent and $\pm 1.0^{\circ} \mathrm{C}$, respectively. According to all these uncertainties and errors, a detailed uncertainty analysis was performed using the method described by Holman [27] for the experimental measurements of the parameters and the total uncertainties of the predicted values

$$
U_{F}=\left[\left(\frac{\partial F}{\partial z_{1}} u_{1}\right)^{2}+\left(\frac{\partial F}{\partial z_{2}} u_{2}\right)^{2}+\cdots+\left(\frac{\partial F}{\partial z_{n}} u_{n}\right)^{2}\right]^{1 / 2}
$$

\section{ANALYSIS}

First, the effects of drying parameters on the drying rate of plums were showed. Although biological materials, such as agricultural products, have high moisture content, generally no constant rate period is seen in drying processes [28]. In this drying period, the dominant diffusion mechanism is liquid and/or vapour diffusion due to the moisture concentration difference and internal conditions such as moisture content, temperature, and structure of the product are important [2, 29]. Fick's second law of diffusion explains this mechanism and the variations of the moisture content of plums during drying were shown as follows

$$
M R=\frac{\left(M_{\mathrm{t}}-M_{\mathrm{e}}\right)}{\left(M_{\mathrm{i}}-M_{\mathrm{e}}\right)}
$$

\subsection{Exergetic analysis of the drying systems}

For a general steady-state, steady-flow process, the three balance equations, namely mass, energy, and exergy balance equations, were employed to find the heat input, the rate of exergy destruction, energy and exergy efficiencies [30].

In general, the mass balance equation can be expressed in the rate form as

$$
\sum \dot{m}_{\mathrm{in}}=\sum \dot{m}_{\mathrm{out}}
$$

The general energy balance can be expressed below as the total energy input equal to the total energy output

$$
\sum \dot{E}_{\text {in }}=\sum \dot{E}_{\text {out }}
$$

with all energy terms as follows

$$
\dot{Q}+\sum \dot{m}_{\text {in }} h_{\text {in }}=\dot{W}+\sum \dot{m}_{\text {out }} h_{\text {out }}
$$

The general exergy balance was expressed in the rate form as

$$
\sum \dot{E} x_{\text {in }}=\sum \dot{E} x_{\text {out }}+\sum \dot{E} x_{\mathrm{d}}
$$

Exergy destruction associated with the irreversibilities (entropy generation) within the system boundaries and exergy losses associated with the transfer of the exergy (through material and energy streams) to the surroundings are given by [31]

$$
\begin{aligned}
& \dot{E} x_{\text {heat }}-\dot{E} x_{\text {work }}+\dot{E} x_{\text {mass,in }}-\dot{E} x_{\text {mass }, \text { out }}=\dot{E} x_{\mathrm{d}} \\
& \sum\left(1-\frac{T_{0}}{T_{\mathrm{b}}}\right) \dot{Q}_{\mathrm{b}}-\dot{W}+\sum \dot{m}_{\text {in }} e x_{\text {in }} \\
& \quad-\sum \dot{m}_{\text {out }} e x_{\text {out }}=\dot{E} x_{\mathrm{d}}
\end{aligned}
$$

where

$$
\dot{E} x=\dot{m} . e x
$$

The specific exergy (ex, flow exergy) of the components, such as the refrigerant, water, and air, was 
calculated by [4]

$$
\begin{aligned}
e x_{\mathrm{r}, \mathrm{w}}= & \left(h-h_{0}\right)-T_{0}\left(s-s_{0}\right) \\
e x_{\mathrm{a}}= & \left(C p_{\mathrm{a}}+\omega_{\mathrm{a}} C p_{\mathrm{v}}\right)\left(T_{\mathrm{a}}-T_{0}\right)-T_{0}\left[\left(C p_{\mathrm{a}}+\omega_{\mathrm{a}} C p_{\mathrm{v}}\right)\right. \\
& \left.\times \ln \left(\frac{T_{\mathrm{a}}}{T_{0}}\right)-\left(R_{\mathrm{a}}+\omega_{\mathrm{a}} R_{\mathrm{v}}\right) \ln \left(\frac{P_{\mathrm{a}}}{P_{0}}\right)\right] \\
& +T_{0}\left[\left(R_{\mathrm{a}}+\omega_{\mathrm{a}} R_{\mathrm{v}}\right) \ln \left(\frac{1+16078 \omega_{0}}{1+16078 \omega_{\mathrm{a}}}\right)\right. \\
& \left.+16078 \omega_{\mathrm{a}} R_{\mathrm{a}} \ln \left(\frac{\omega_{\mathrm{a}}}{\omega_{0}}\right)\right]
\end{aligned}
$$

The energy-based (or first law) performances of the HP unit and the whole HP dryer system were evaluated using the following relations

$$
\begin{aligned}
& \operatorname{COP}_{\mathrm{HP}, \text { theoretical }}=\frac{\left(h_{2, \mathrm{rs}}-h_{3, \mathrm{r}}\right)}{\left(h_{2, \mathrm{rs}}-h_{1, \mathrm{r}}\right)} \\
& \mathrm{COP}_{\mathrm{HP}, \text { act }}=\frac{\dot{Q}_{\text {cond }}}{\dot{W}_{\text {comp }}}
\end{aligned}
$$

Exergy efficiency is defined as the ratio of total exergy out to total exergy in, where 'out' refers to 'net output' or 'product' or 'desired value', and 'in' refers to 'given' or 'used' or 'fuel'

$$
\eta=\frac{\dot{E} x_{\text {out }}}{\dot{E} x_{\text {in }}} \times 100
$$

Van Gool [32] has proposed that maximum improvement in the exergy efficiency for a process or system was obviously achieved when the difference between the total exergy output and total exergy input was minimized. Consequently, he suggested that it was useful to employ the concept of an exergetic 'improvement potential' in the rate form when analysing different processes or sectors of the economy and this improvement potential in the rate form was given by [33]

$$
I \dot{P}=(1-\eta)\left(\dot{E} x_{\text {in }}-\dot{E} x_{\text {out }}\right)
$$

Thermodynamic analysis of a system component may also be performed using the following parameter, named the exergetic factor [34]

$$
f_{\mathrm{i}}=\frac{\dot{F}_{\mathrm{i}}}{\dot{F}_{\text {total }}} \times 100
$$

Mass and energy balances as well as exergy destructions and exergetic efficiencies obtained from exergy balances for each of the drying system components illustrated in Figs 1-3 were derived as follows.

Fan and heater combination (I)

$$
\begin{aligned}
& \dot{W}_{\text {fan-heater,elec }}=\frac{V_{\text {fan-heater }} I_{\text {fan-heater }} \sqrt{3}}{1000} \cos \varphi(\text { for TD }) \\
& \dot{W}_{\text {fan-heater,elec }}=\frac{V_{\text {fan-heater }} I_{\text {fan-heater }}}{1000}(\text { for FBD) } \\
& \dot{W}_{\text {fan-heater }}=\dot{W}_{\text {fan-heater,elec }} \eta_{\text {fan-heater,elec }} \eta_{\text {fan-heater,mech }} \\
& \eta_{\text {fan-heater }}=\frac{(13 \mathrm{~b})}{\dot{E} x_{2, \mathrm{a}}-\dot{E} x_{1, \mathrm{a}}} \\
& \dot{W}_{\text {fan-heater }}
\end{aligned}
$$

Drying cabinet (II)

$$
\eta_{\text {dcab }}=\frac{\dot{E} x_{6, \mathrm{a}}}{\dot{E} x_{5, \mathrm{a}}}
$$

Compressor (III)

$$
\begin{aligned}
& \dot{W}_{\text {comp,elec }}=\frac{V_{\text {comp }} I_{\text {comp }} \sqrt{3}}{1000} \cos \varphi \\
& \dot{W}_{\text {comp }}=\dot{W}_{\text {comp,elec }} \eta_{\text {comp,elec }} \eta_{\text {comp,mech }} \\
& \eta_{\text {comp }}=\frac{\dot{E} x_{2, \text { r,act }}-\dot{E} x_{1, \mathrm{r}}}{\dot{W}_{\text {comp }}}
\end{aligned}
$$

Condenser (IV)

$$
\eta_{\text {cond }}=\frac{\dot{E} x_{1, \mathrm{a}}-\dot{E} x_{7, \mathrm{a}}}{\dot{E} x_{2, \mathrm{r}, \mathrm{act}}-\dot{E} x_{3, \mathrm{r}}}
$$

Expansion valve $(\mathrm{V})$

$$
\eta_{\exp }=\frac{\dot{E} x_{4, \mathrm{r}}}{\dot{E} x_{3, \mathrm{r}}}
$$

Fan \& Heater Combination

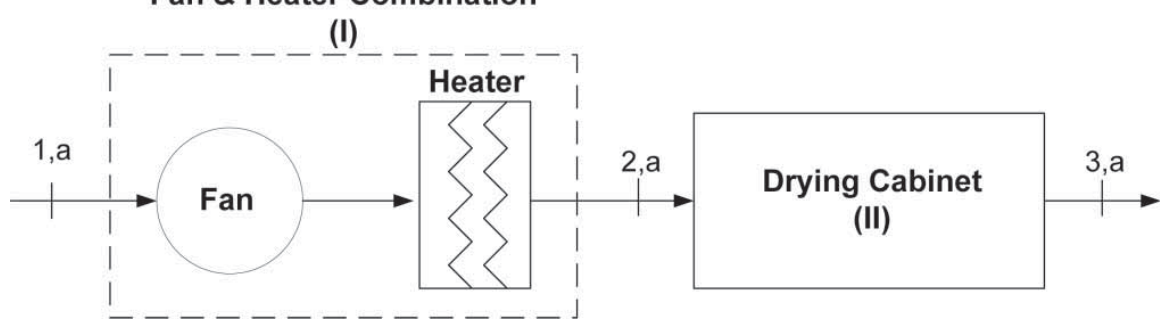

Fig. 1 Schematic of the tray drier with coded points used in equations 


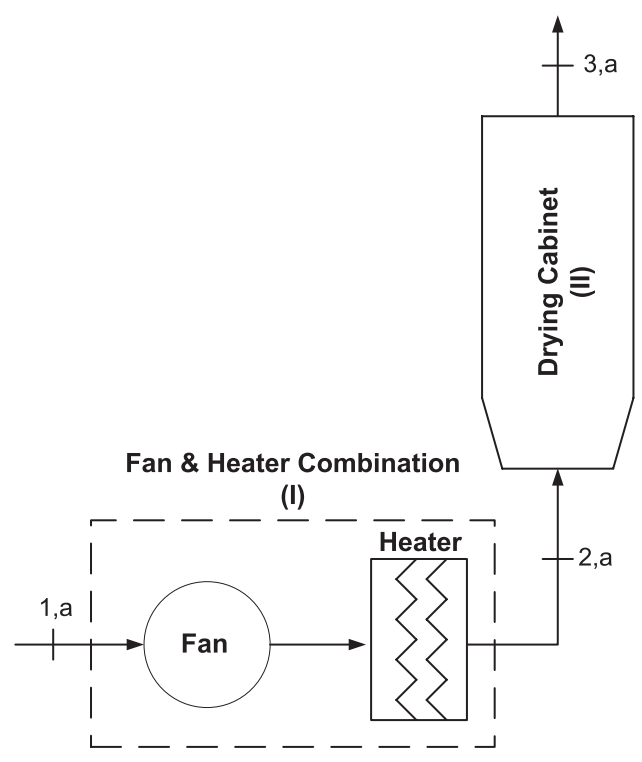

Fig. 2 Schematic of the fluid bed drier with coded points used in equations

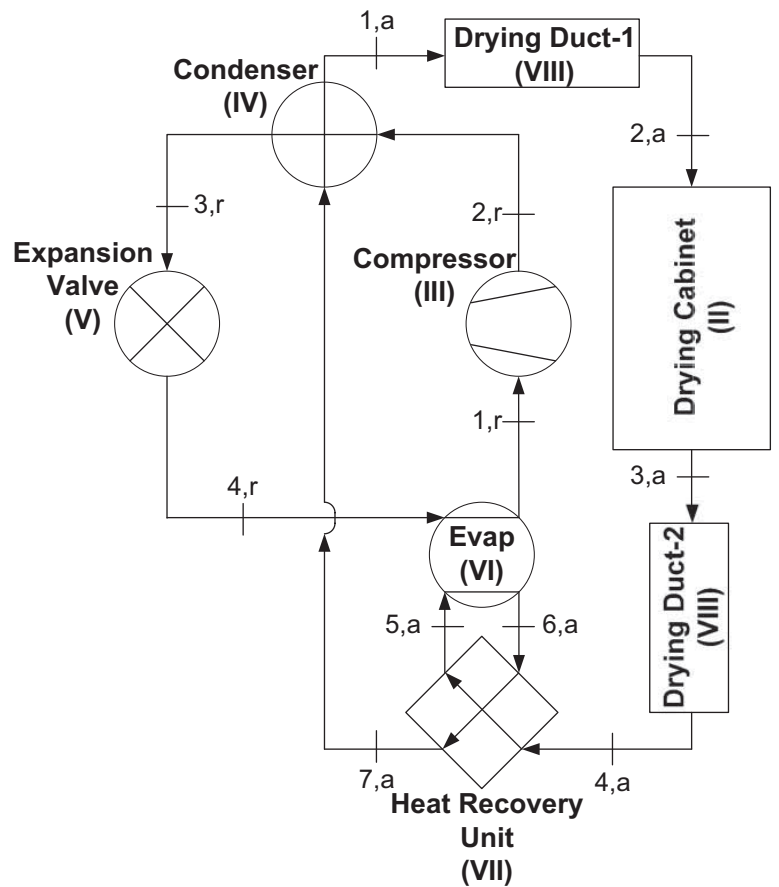

Fig. 3 Schematic of the heat pump drier with coded points used in equations

Evaporator (VI)

$$
\eta_{\text {evap }}=\frac{\dot{E} x_{5, \mathrm{a}}-\dot{E} x_{6, \mathrm{a}}}{\dot{E} x_{1, \mathrm{r}}-\dot{E} x_{4, \mathrm{r}}}
$$

Heat recovery unit (VII)

$$
\eta_{\text {recovery }}=\frac{\dot{E} x_{7, \mathrm{a}}+\dot{E} x_{6, \mathrm{a}}}{\dot{E} x_{4, \mathrm{a}}+\dot{E} x_{5, \mathrm{a}}}
$$

Drying ducts (VIII)

$$
\begin{aligned}
& \eta_{\text {dduct }, 1}=\frac{\dot{E} x_{2, \mathrm{a}}}{\dot{E} x_{1, \mathrm{a}}} \\
& \eta_{\text {dduct }, 2}=\frac{\dot{E} x_{4, \mathrm{a}}}{\dot{E} x_{3, \mathrm{a}}} \\
& \eta_{\text {dduct,total }}=\frac{\dot{E} x_{2, \mathrm{a}}+\dot{E} x_{4, \mathrm{a}}}{\dot{E} x_{1, \mathrm{a}}+\dot{E} x_{3, \mathrm{a}}}
\end{aligned}
$$

\subsection{Assumptions made}

The following assumptions were made during the analyses.

1. All processes were in steady state and steady flow with negligible potential and kinetic energy effects and no chemical or nuclear reactions.

2. The heat transfer to the system and the work transfer from the system were positive.

3. The heat transfer and refrigerant pressure drops in the tubing connecting the components were neglected since their lengths are short.

4. The fan mechanical $\eta_{\text {fan,mech }}$ and the fan motor electrical $\eta_{\text {fan,elec }}$ efficiencies were 40 and 70 per cent, respectively. These values were based on the fan characteristic data and the proposed efficiency values for a small propeller fan [35].

5. The heaters electrical $\eta_{\text {heater,elec }}$ efficiencies were assumed as 99 per cent.

6 . The compressor mechanical $\eta_{\text {comp,mech }}$ and the compressor motor electrical $\eta_{\text {comp,elec }}$ efficiencies were 72 and 75 per cent, respectively [36].

7. Air was an ideal gas with a constant specific heat.

8. The reference-dead state conditions were determined as $T_{0}=10^{\circ} \mathrm{C}, P_{0}=101.325 \mathrm{kPa}$, and $\phi_{0}=$ 60 per cent for air, and $T_{0}=10^{\circ} \mathrm{C}, P_{0}=101.325 \mathrm{kPa}$ for refrigerant.

9. $C p_{\mathrm{a}}=1.005 \mathrm{~kJ} / \mathrm{kg}^{\circ} \mathrm{C}, \quad C p_{\mathrm{v}}=1.872 \mathrm{~kJ} / \mathrm{kg}^{\circ} \mathrm{C}, \quad R_{\mathrm{a}}=$ $0.287 \mathrm{~kJ} / \mathrm{kg} \mathrm{K}$, and $R_{\mathrm{v}}=0.4615 \mathrm{~kJ} / \mathrm{kg} \mathrm{K}$ were assumed as constant in all calculations [37]. The thermodynamic properties of air and R-407C were found using the Engineering Equation Solver software package [38].

\section{RESULTS AND DISCUSSION}

The detailed uncertainty analysis was performed for the experimental measurements of parameters and total uncertainties of predicted values. Results of uncertainty analysis are listed in Table 1 . The effect of drying air temperature on the variation of moisture content of plums with drying time is illustrated in Fig. 4. It is clear from this figure that the drying rate increased as the drying air temperature increased. The thermodynamic analyses of drying systems were carried out by using data from the experiments conducted 
Table 1 Uncertainties of the experimental measurements and total uncertainties for predicted values

\begin{tabular}{|c|c|c|}
\hline Parameter & Unit & Comment \\
\hline \multicolumn{3}{|l|}{ Experimental measurements } \\
\hline $\begin{array}{l}\text { Uncertainty in the temperature } \\
\text { measurement }\end{array}$ & ${ }^{\circ} \mathrm{C}$ & \pm 0.224 \\
\hline Uncertainty in the weight measurement & $\mathrm{g}$ & \pm 0.00051 \\
\hline $\begin{array}{l}\text { Uncertainty in the air velocity } \\
\text { measurement }\end{array}$ & $\mathrm{m} / \mathrm{s}$ & \pm 0.21 \\
\hline $\begin{array}{l}\text { Uncertainty in the measurement of } \\
\text { relative humidity of air }\end{array}$ & $\%$ & \pm 0.41 \\
\hline $\begin{array}{l}\text { Uncertainty in the pressure } \\
\text { measurement }\end{array}$ & $\mathrm{kPa}$ & $\pm 1.0 \%$ \\
\hline $\begin{array}{l}\text { Uncertainty in the surface temperature } \\
\text { measurement }\end{array}$ & ${ }^{\circ} \mathrm{C}$ & \pm 1.0 \\
\hline \multicolumn{3}{|l|}{ Predicted values } \\
\hline Total uncertainty for $\dot{E} x_{\mathrm{in}}$ & kW & $\pm 0.99 \%^{\mathrm{a}}$ \\
\hline Total uncertainty for $\dot{E} x_{\text {out }}$ & kW & $\pm 1.03 \%^{\mathrm{b}}$ \\
\hline Total uncertainty for $\eta$ & $\%$ & $\pm 1.51 \%^{\mathrm{c}}$ \\
\hline \multicolumn{3}{|l|}{ For fluid bed drier } \\
\hline Total uncertainty for $\dot{E} x_{\text {in }}$ & $\mathrm{kW}$ & $\pm 0.97 \% \mathrm{~d}$ \\
\hline Total uncertainty for $\dot{E} x_{\text {out }}$ & $\mathrm{kW}$ & $\pm 1.01 \%^{\mathrm{e}}$ \\
\hline Total uncertainty for $\eta$ & $\%$ & $\pm 1.52 \%^{\mathrm{f}}$ \\
\hline \multicolumn{3}{|l|}{ For the heat pump drier } \\
\hline Total uncertainty for $\dot{E} x_{\mathrm{in}}$ & $\mathrm{kW}$ & $\pm 1.05 \% \mathrm{~g}$ \\
\hline Total uncertainty for $\dot{E} x_{\text {out }}$ & $\mathrm{kW}$ & $\pm 1.13 \%^{\mathrm{h}}$ \\
\hline Total uncertainty for $\eta$ & $\%$ & $\pm 1.75 \%^{\mathrm{i}}$ \\
\hline
\end{tabular}

${ }^{\text {a }}$ Nominal value $=0.538$

${ }^{\mathrm{b}}$ Nominal value $=0.511$

${ }^{\mathrm{c}}$ Nominal value $=94.94$

$\mathrm{d}_{\text {Nominal value }}=0.123$

${ }^{\mathrm{e}}$ Nominal value $=0.113$

${ }^{\mathrm{f}}$ Nominal value $=92.06$

${ }^{\mathrm{g}}$ Nominal value $=2.414$

$\mathrm{h}_{\text {Nominal value }}=2.127$

${ }^{\mathrm{i}}$ Nominal value $=88.09$

at different drying air temperatures $\left(45,50\right.$, and $\left.55^{\circ} \mathrm{C}\right)$. Exergy analyses were performed to evaluate the performance of the driers (Tables 2-4).
The most important system component of the tray drier was the fan-heater combination (Table 2), and it should be improved to increase the efficiency of the drier. It not only had low exergetic efficiency $\eta$ and high improvement potential (IP) rate values, but also its exergetic factor $f$ was 80 per cent. This proved that the fan-heater combination significantly affected the system efficiency. On the other hand, the $\eta$ values for the fan-heater combination and the whole system increased as the drying air temperature increased. It could be concluded that the best way to improve the system efficiency was to recycle the heated air since approximately one-fourth of the exergy inflow was thrown away as waste exergy (Fig. 5).

The results of exergy analysis for the fluid bed drier are summarized in Table 3. The importance of the components of the fluid bed drier was similar to the tray drier. But the fan-heater combination of the fluid bed drier affected the whole system efficiency more than that of the tray drier ( $f \approx 87$ per cent). Since the efficiency of the fan-heater combination of the fluid bed drier was lower than that of the tray drier, the exergetic efficiency of the whole system was lower. Furthermore, $\eta$ values for all components and the whole system increased and IP rate values decreased with the rise in the drying temperature. A total of 12.5 per cent of the exergy inflow was thrown away as waste exergy (Fig. 6). Therefore, recycling the heated air to the system inlet would improve the system efficiency, but its importance was not so much as compared to the tray drier.

The energy-based (or first law) performance measure of the HP unit was calculated. Theoretical COP values of the HP unit were found to be in the range of 3.92-4.35 and they decreased with the increase in drying temperature. Although actual COP values were obtained to vary between 2.56 and 2.81 for the HP

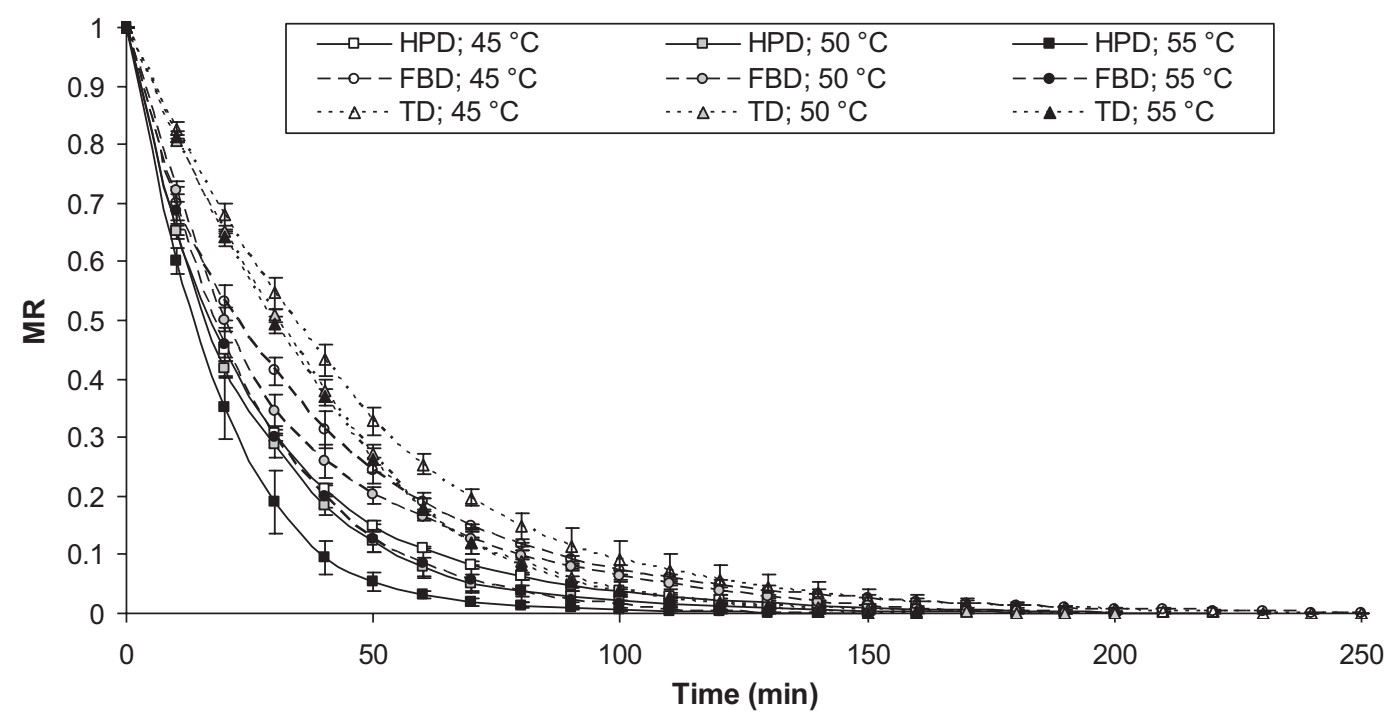

Fig. 4 The variations of fractional moisture ratio of plums with drying time 
Table 2 Energetic, exergetic, and thermodynamic analysis data provided for the tray drier

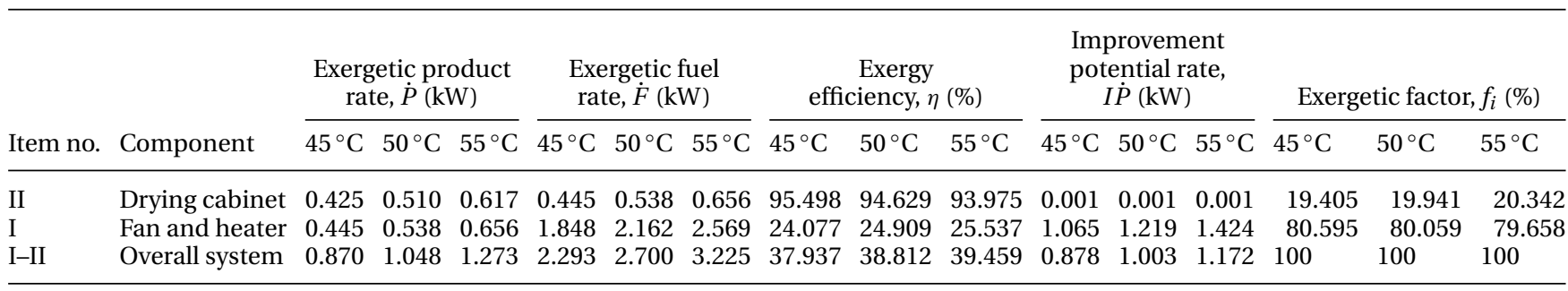

Table 3 Energetic, exergetic, and thermodynamic analysis data provided for the fluid bed drier

\begin{tabular}{|c|c|c|c|c|c|c|c|c|c|c|c|c|c|c|c|c|}
\hline \multirow{2}{*}{$\begin{array}{l}\text { Item } \\
\text { no. }\end{array}$} & \multirow[b]{2}{*}{ Component } & \multicolumn{3}{|c|}{$\begin{array}{l}\text { Exergetic product } \\
\text { rate, } \dot{P}(\mathrm{~kW})\end{array}$} & \multicolumn{3}{|c|}{$\begin{array}{l}\text { Exergetic fuel } \\
\text { rate, } \dot{F}(\mathrm{~kW})\end{array}$} & \multicolumn{3}{|c|}{ Exergy efficiency, $\eta$ (\%) } & \multicolumn{3}{|c|}{$\begin{array}{c}\text { Improvement } \\
\text { potential rate, } \\
I \dot{P}(\mathrm{~kW})\end{array}$} & \multicolumn{3}{|c|}{ Exergetic factor, $f_{i}(\%)$} \\
\hline & & $45^{\circ} \mathrm{C}$ & $50^{\circ} \mathrm{C}$ & $55^{\circ} \mathrm{C}$ & $45^{\circ} \mathrm{C}$ & $50^{\circ} \mathrm{C}$ & $55^{\circ} \mathrm{C}$ & $45^{\circ} \mathrm{C}$ & $50^{\circ} \mathrm{C}$ & $55^{\circ} \mathrm{C}$ & $45^{\circ} \mathrm{C}$ & $50^{\circ} \mathrm{C}$ & $55^{\circ} \mathrm{C}$ & $45^{\circ} \mathrm{C}$ & $50^{\circ} \mathrm{C}$ & $55^{\circ} \mathrm{C}$ \\
\hline II & Drying cabinet & 0.090 & 0.111 & 0.130 & 0.097 & 0.123 & 0.147 & 92.522 & 90.406 & 88.272 & 0.0001 & 0.0002 & 0.0002 & 12.501 & 12.331 & 12.127 \\
\hline I & Fan and heater & 0.097 & 0.123 & 0.147 & 0.678 & 0.872 & 1.068 & 14.287 & 14.065 & 13.800 & 0.498 & 0.644 & 0.794 & 87.499 & 87.669 & 87.873 \\
\hline I-II & Overall system & 0.186 & 0.233 & 0.277 & 0.775 & 0.994 & 1.215 & 24.068 & 23.479 & 22.831 & 0.442 & 0.574 & 0.712 & 100 & 100 & 100 \\
\hline
\end{tabular}

Table 4 Energetic, exergetic, and thermodynamic analysis data provided for the heat pump drier

\begin{tabular}{|c|c|c|c|c|c|c|c|c|c|c|c|c|c|c|c|c|}
\hline \multirow{2}{*}{$\begin{array}{l}\text { Item } \\
\text { no. }\end{array}$} & \multirow[b]{2}{*}{ Component } & \multicolumn{3}{|c|}{$\begin{array}{l}\text { Exergetic product } \\
\text { rate, } \dot{P}(\mathrm{~kW})\end{array}$} & \multicolumn{3}{|c|}{$\begin{array}{l}\text { Exergetic fuel } \\
\text { rate, } \dot{F}(\mathrm{~kW})\end{array}$} & \multicolumn{3}{|c|}{$\begin{array}{c}\text { Exergy } \\
\text { efficiency, } \eta(\%)\end{array}$} & \multicolumn{3}{|c|}{$\begin{array}{l}\text { Improvement } \\
\text { potential rate, } \\
I \dot{P}(\mathrm{~kW})\end{array}$} & \multicolumn{3}{|c|}{ Exergetic factor, $f_{i}(\%)$} \\
\hline & & $45^{\circ} \mathrm{C}$ & $50^{\circ} \mathrm{C}$ & $55^{\circ} \mathrm{C}$ & $45^{\circ} \mathrm{C}$ & $50^{\circ} \mathrm{C}$ & $55^{\circ} \mathrm{C}$ & $45^{\circ} \mathrm{C}$ & $50^{\circ} \mathrm{C}$ & $55^{\circ} \mathrm{C}$ & $45^{\circ} \mathrm{C}$ & $50^{\circ} \mathrm{C}$ & $55^{\circ} \mathrm{C}$ & $45^{\circ} \mathrm{C}$ & $50^{\circ} \mathrm{C}$ & $55^{\circ} \mathrm{C}$ \\
\hline III & Compressor & 3.412 & 3.892 & 4.936 & 6.513 & 6.863 & 7.688 & 52.380 & 56.713 & 64.203 & 1.477 & 1.286 & 0.985 & 31.728 & 29.781 & 27.026 \\
\hline IV & Condenser & 1.502 & 1.774 & 2.321 & 1.734 & 2.064 & 2.751 & 86.623 & 85.927 & 84.350 & 0.031 & 0.041 & 0.067 & 8.445 & 8.958 & 9.672 \\
\hline V & Expansion valve & 3.356 & 3.774 & 4.583 & 4.577 & 5.181 & 6.384 & 73.336 & 72.847 & 71.789 & 0.325 & 0.382 & 0.508 & 22.294 & 22.481 & 22.444 \\
\hline VI & Evaporator & 0.458 & 0.421 & 0.384 & 0.528 & 0.608 & 0.846 & 86.745 & 69.307 & 45.323 & 0.131 & 0.316 & 0.672 & 2.570 & 2.636 & 2.975 \\
\hline VII & Heat recovery & 0.492 & 0.572 & 0.729 & 1.193 & 1.343 & 1.634 & 41.229 & 42.623 & 44.637 & 0.412 & 0.442 & 0.501 & 5.813 & 5.828 & 5.744 \\
\hline VIII & Drying ducts & 3.869 & 4.464 & 5.822 & 3.923 & 4.572 & 5.986 & 98.601 & 97.632 & 97.259 & 0.001 & 0.003 & 0.004 & 19.113 & 19.839 & 21.043 \\
\hline II & Drying cabinet & 1.840 & 2.124 & 2.748 & 2.060 & 2.414 & 3.156 & 89.294 & 87.978 & 87.045 & 0.024 & 0.035 & 0.053 & 10.037 & 10.476 & 11.096 \\
\hline II-VIII & Overall system & 14.927 & 17.021 & 21.522 & 20.528 & 23.045 & 28.446 & 72.718 & 73.861 & 75.659 & 1.528 & 1.574 & 1.685 & 100 & 100 & 100 \\
\hline
\end{tabular}

unit, they were increased as the drying temperature increased on the contrary to theoretical COP values.

Table 4 illustrates exergetic analysis data provided for the HP drier. The highest IP rate and $f$ values occurred in the motor-compressor assembly. The other important system components were the HRU, expansion valve, and evaporator according to the IP rate values. Furthermore, the sum of $f$ values of the compressor, expansion valve, and drying ducts totaled more than 70 per cent, so these components handled the high amount of exergy in the system.

$\eta$, IP rate, and $f$ values of the compressor were obtained to vary between 52.38 and 64.20 per cent, 0.99 and $1.48 \mathrm{~kW}$, and 27.03 and 31.73 per cent, respectively. $\eta$ values increased as the drying temperature increased on the contrary to IP rate and $f$ values. The total magnitude of the losses was over 54 per cent of the actual power input, while the mechanicalelectrical losses accounted for 46 per cent of that. The mechanical-electrical losses are due to imperfect electrical, mechanical, and isentropic efficiencies, and emphasize the need for paying close attention to the selection of this equipment, since components of inferior performance can considerably reduce the overall system performance. Since compressor power depends strongly on the inlet and outlet pressures, any heat exchanger improvements that reduce the temperature difference will reduce compressor power by bringing the condensing and evaporating temperatures closer together. It is obvious that from a design standpoint, the compressor irreversibility can be reduced independently. Recently, scroll-type compressors that were used in this study were recommended due to their high efficiency $[\mathbf{3 0}, \mathbf{3 6}]$. An alternative approach to this problem is using the primary energy sources instead of electricity. In this way, the losses arisen from energy conversion processes of electricity production can be recovered, so gas-engine-driven HP systems gain importance [39-41].

Other important components of the system were heat exchangers (condenser, evaporator, and HRU). Although $f$ values of the evaporator and HRU were 8.2 times and 3.9 times lower than the expansion valve, their IP rate values were approximately similar to the expansion valve. It was concluded that it was 


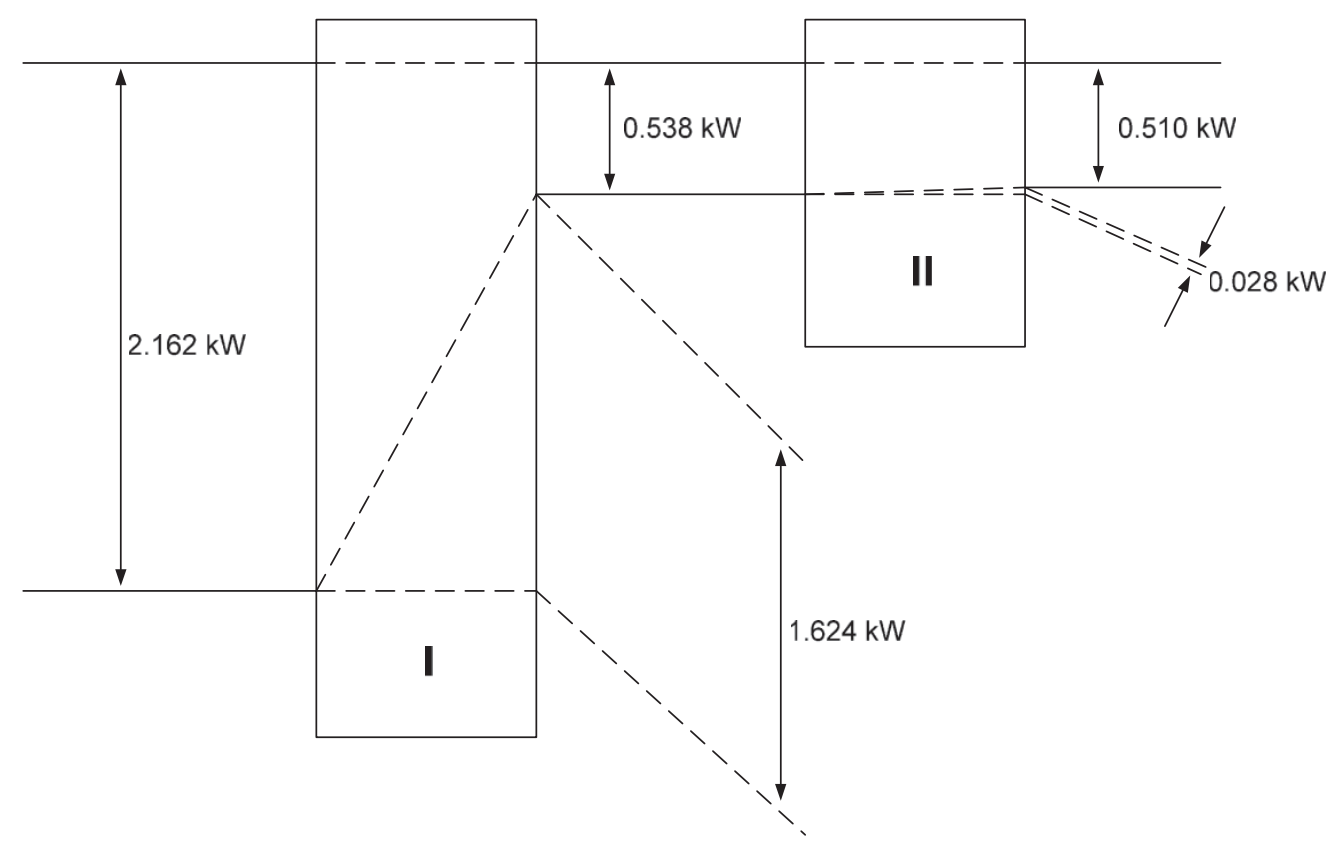

Fig. 5 Exergy loss and flow diagram (Grassmann diagram) for the tray drier at $50^{\circ} \mathrm{C}$

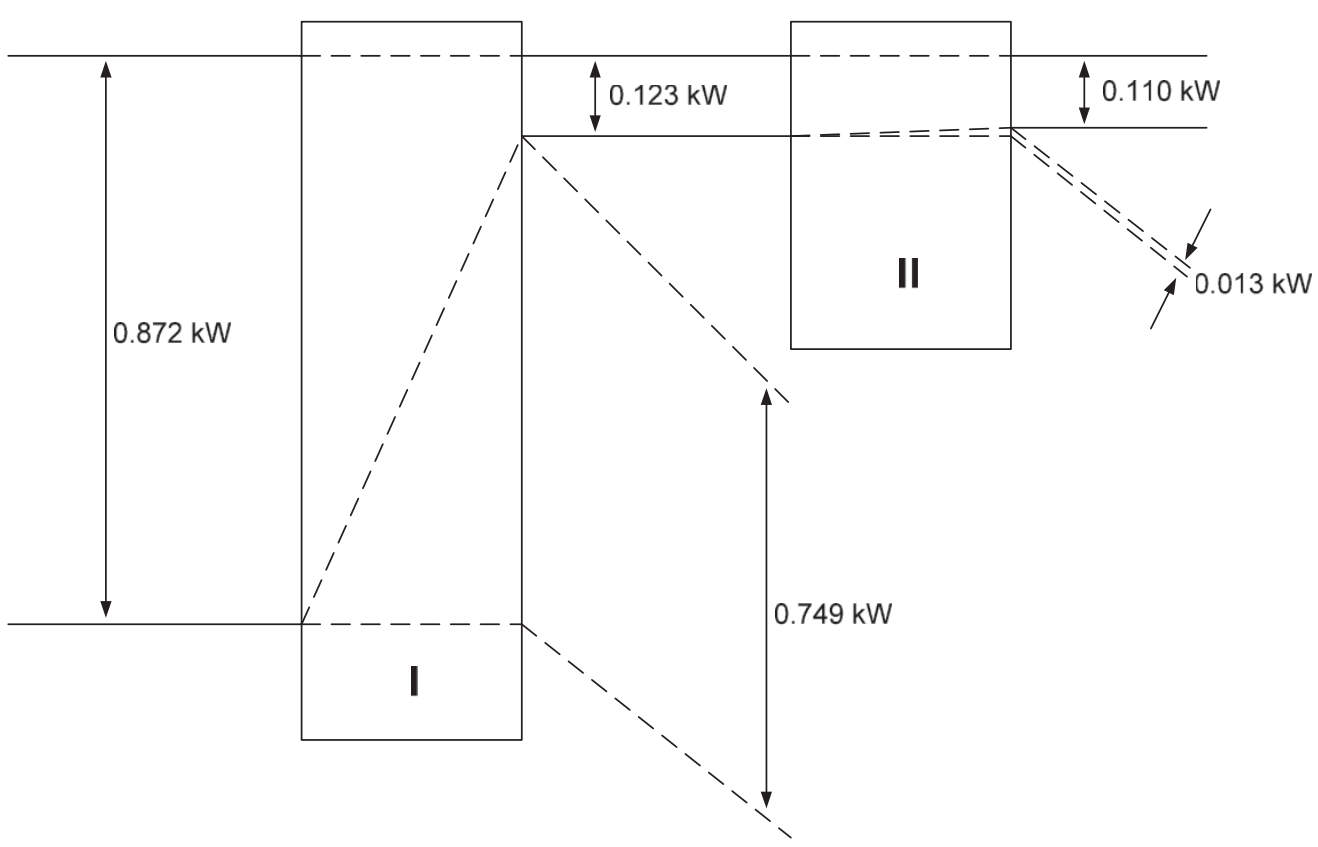

Fig. 6 Exergy loss and flow diagram (Grassmann diagram) for the fluid bed drier at $50{ }^{\circ} \mathrm{C}$

important to reduce irreversibilities in the evaporator and HRU for improving the system performance. On the other hand, the condenser was separated from other heat exchangers in the system. Although $f$ values of the condenser were higher, IP rate values were the lowest in the HP unit. The reason is that the highest $\eta$ values were obtained from the condenser in the HP unit. Another important note according to the results of the exergy analysis of the HP drier was that the rise in drying temperature caused huge decrease in the efficiency of the evaporator. It could be the result of increasing irreversibility as the temperature difference increased. Irreversibilities in the heat exchangers could occur due to the temperature differences between the two heat exchanger fluids, pressure losses, flow imbalances, and heat transfer with the environment.

The expansion valve had the highest $\eta$ values after the condenser in the HP unit. The irreversibility was in the capillary tube due to the pressure drop of the refrigerant passing through it. The only way to eliminate throttling loss would be to replace the capillary 
tube (the expansion device) with an isentropic turbine (an isentropic expander) and to recover some shaft work from the pressure drop [30].

High exergetic efficiency values and low relative irreversibility values were obtained from drying ducts and drying cabinet in this study. Although $\eta$ values of the drying cabinet of the tray drier and fluid bed drier were slightly higher those of the HP drier, the drying capacity and dimension of the systems were different. The inefficiencies of the drying cabinet were owing to the heat losses from the drier walls and high efficiency values could be the reason of an excellent insulation or a low heat transfer surface area. The heat transfer surface areas of the drying cabinet of the tray drier, fluid bed drier, and HP drier used in this study were $0.48,0.165$, and $12 \mathrm{~m}^{2}$, respectively. The HP drier was a pilot-scaled system, so its energy load was higher, as could be seen from its fuel rate. It may be concluded that the HP drier used in this study had an excellent insulation and was airproof (Table 4).

Figure 7 illustrates the Grassmann diagram for the HP drier. This diagram gives the quantitative information related to the share of the exergy input to the HP drier. While the $\eta$ values were found to vary between 72.72 and 75.66 per cent, the rise in the drying temperature increased the drier's efficiency.

A comparison of the exergetic performance of the driers used in this study with the varying drying temperatures is shown in Fig. 8. Although the HP drier had a high energy load and had been more affected from heat losses, it was obvious that the most efficient drier was the HP drier.

HP systems are heat-generating devices that transfer heat from a low-temperature medium to hightemperature one and are used in either hot water or space heating applications. HPs have been used

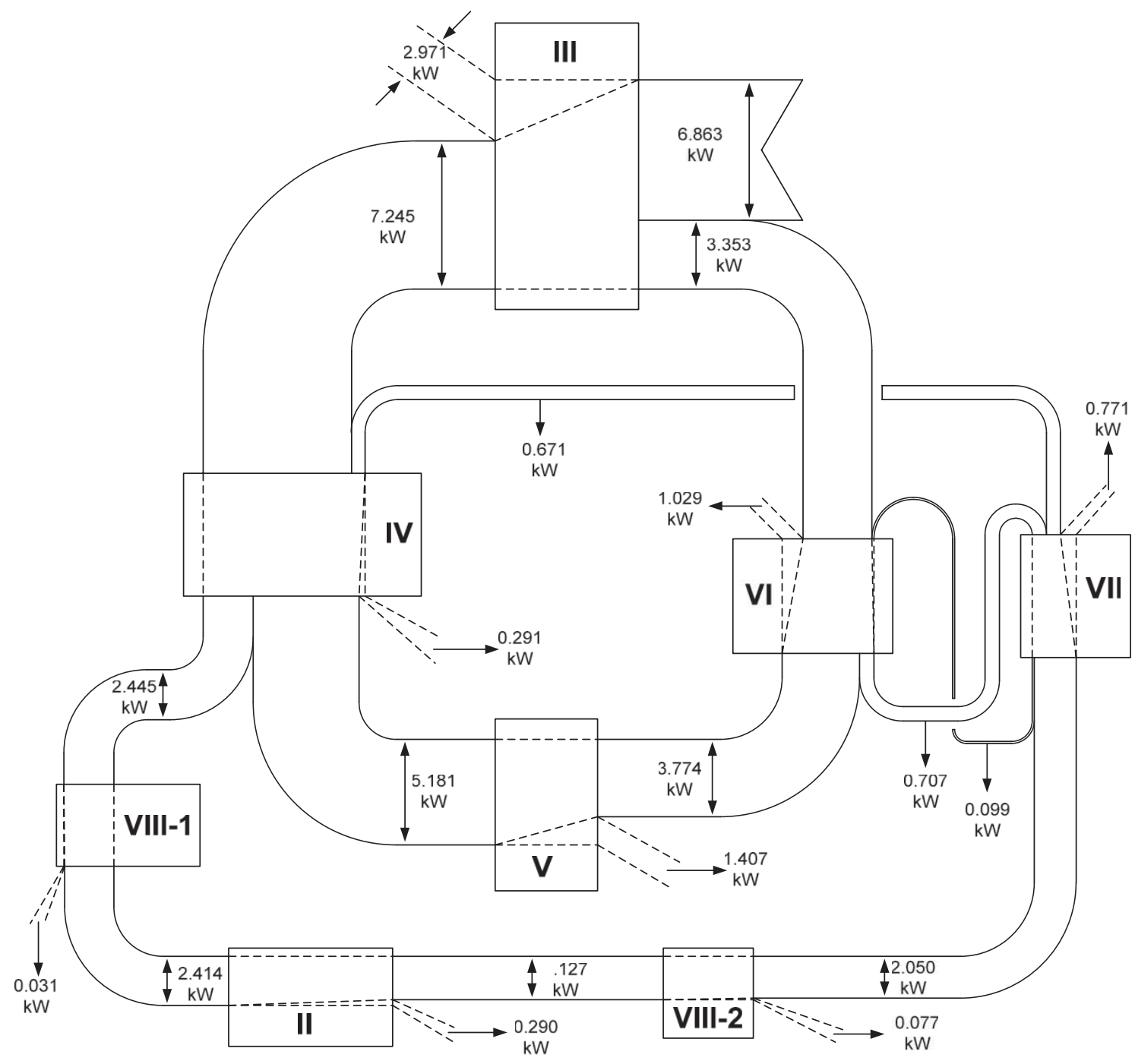

Fig. 7 Exergy loss and flow diagram (Grassmann diagram) for the heat pump drier at $50{ }^{\circ} \mathrm{C}$ 


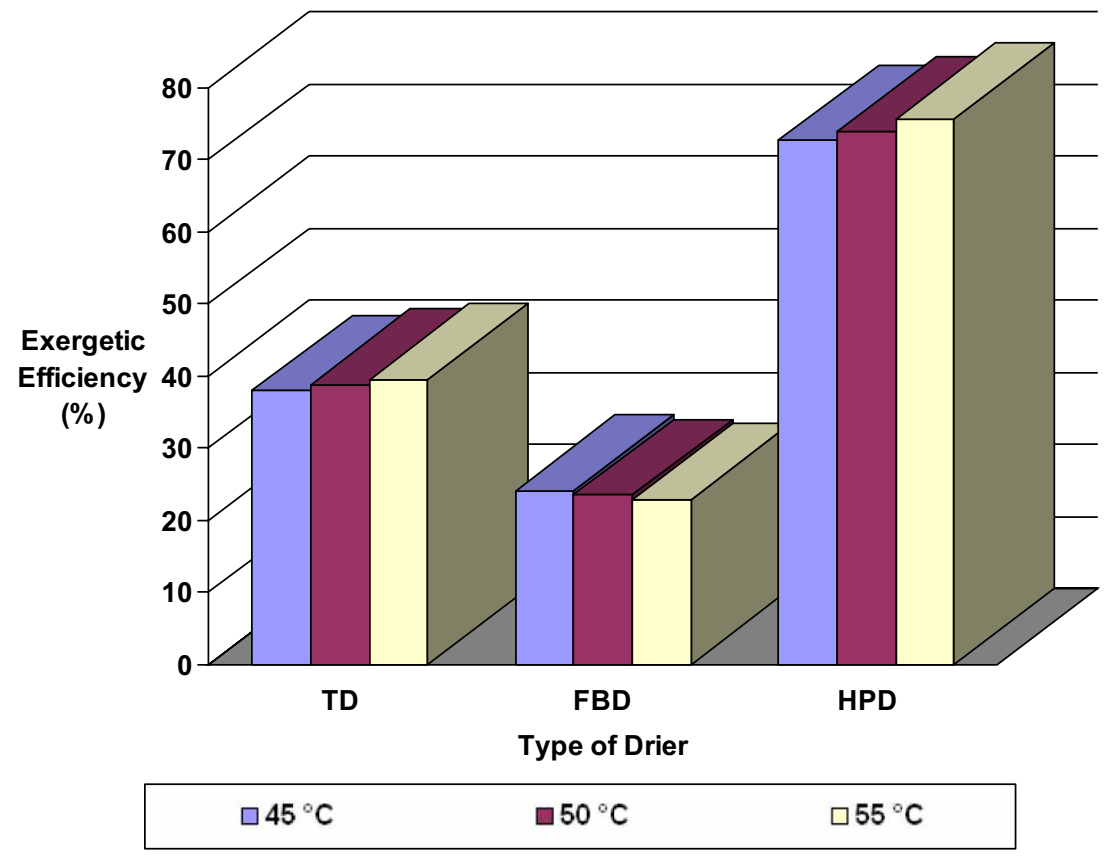

Fig. 8 Comparison of the exergetic efficiencies of the driers with varying drying temperatures (TD: tray drier, FBD: fluid bed drier, HPD: heat pump drier)

mainly for space heating and water heating/cooling purposes, but many studies have been progressed in its industrial applications especially in dehumidification and in drying agricultural products which are energy-intensive processes [42-44]. The present study gained similar results with the literature $[\mathbf{4 5 - 4 7 ]}$ and showed that HP systems were efficient systems and could be used or integrated to the energy-intensive processes.

\section{CONCLUSIONS}

In this study, the exergetic performance of three different food driers was assessed. Grassmann diagrams of these driers were given, while the components of the driers were analysed separately and effects of the process condition (drying temperature) on the performance of the driers were discussed.

The following main conclusions may be drawn from the main results of the present study.

1. The fan-heater combination significantly affected the efficiencies of the whole system in the tray and fluid bed driers.

2. The most important system component of the HP drier was the motor-compressor assembly because of its highest improvement potential rate and exergetic factor values.

3. The HP drier had the highest exergetic efficiency values in the range of 72.72-75.66 per cent, followed by the tray drier between 37.94 and 39.46 per cent, and the fluid bed drier between 22.83 and 24.07 per cent.
4. While exergetic efficiencies of the tray and HP driers increased with the rise in the drying temperature on the contrary to the efficiencies of the fluid bed drier.

5. The $\mathrm{COP}_{\mathrm{HP}}$,theoretical values were found to be in the range of 3.92-4.35 and the $\mathrm{COP}_{\mathrm{HP} \text {,actual }}$ values were obtained to be 2.56-2.81 for the HP unit.

6 . The most efficient drier in this study was determined to be the HP drier.

\section{ACKNOWLEDGEMENTS}

The authors are grateful for the financial support provided for the project entitled 'Design, test and performance evaluation of a gas-engine-driven solar assisted band conveyor heat pump drying system' under project no. 106M482 by The Scientific and Technological Research Council of Turkey (TUBITAK). They are also grateful to the reviewers for the valuable comments, which have been utilized to improve the quality of the article.

(C) Authors 2010

\section{REFERENCES}

1 Mujumdar, A. S. Drying fundamentals. In Industrial drying of foods (Ed. C. G. J. Baker), 1997, pp. 7-30 (Chapman \& Hall, London).

2 Erbay, Z. and Icier, F. A review of thin layer drying of foods: theory, modeling and experimental results. Critical Reviews in Food Science and Nutrition (in press). 
3 Keey, R. B. Introduction. In Drying principles and practice (Ed. R. B. Keey), 1972, pp. 1-18 (Pergamon Press, Oxford).

4 Dincer, I. and Sahin, A. Z. A new model for thermodynamic analysis of a drying process. Int. J. Heat Mass Transfer, 2004, 47, 645-652.

5 Kuzgunkaya, E. H. and Hepbasli, A. Exergetic performance assessment of a ground-source heat pump drying system. Int. J. Energy Res., 2007, 31, 760-777.

6 Radivoje, T. Mathematical model for exergy analysis for drying plants. Drying Technol., 1995, 13(1), 437-445.

7 Bruttini, R., Crosser, O. K., and Liapis, A. I. Exergy analysis for the freezing stage of the freeze drying process. Drying Technol., 2001, 19(9), 2303-2313.

8 Syahrul, S., Dincer, I., and Hamdullahpur, F. Thermodynamic modeling of fluidized bed drying of moist particles. Int. J. Therm. Sci., 2003, 42, 691-701.

9 Midilli, A. and Kucuk, H. Energy and exergy analysis of solar drying process of pistachio. Energy, 2003, 28, 539-556.

10 Akpinar, E. K. Energy and exergy analyses of drying of red pepper slices in a convective type dryer. Int. Commun. Heat Mass Transfer, 2004, 31(8), 1165-1176.

11 Akpinar, E. K., Midilli, A., and Bicer, Y. Energy and exergy of potato drying process via cyclone type dryer. Energy Convers. Manage., 2005, 46(15-16), 2530-2552.

12 Akpinar, E. K., Midilli, A., and Bicer, Y. Thermodynamic analysis of the apple drying process. Proc. IMechE, Part E:J. Process Mechanical Engineering, 2005, 219(E1), 1-14. DOI: 10.1243/095440805X6991.

13 Akpinar, E. K., Midilli, A., and Bicer, Y. The first and second law analyses of thermodynamic of pumpkin drying process. J. Food Eng., 2006, 72(4), 320-331.

14 Kuzgunkaya, E. H. and Hepbasli, A. Exergetic evaluation of drying of laurel leaves in a vertical ground-source heat pump drying cabinet. Int. J. Energy Res., 2007, 31, 248-258.

15 Colak, N. and Hepbasli, A. Performance analysis of drying of green olive in a tray dryer. J. Food Eng., 2007, 20, 1188-1193.

16 Ozgener, L. Exergoeconomic analysis of small industrial pasta drying systems. Proc. IMechE, Part A: J. Power and Energy, 2008, 221(A7), 899-906. DOI: 10.1243/09576509JPE481.

17 Colak, N., Kuzgunkaya, E., and Hepbasli, A. Exergetic assessment of drying of mint leaves in a heat pump dryer. J. Food Process Eng., 2008, 31, 281-298.

18 Aghbashlo, M., Kianmehr, M. H., and Arabhosseini, A. Energy and exergy analyses of thin-layer drying of potato slices in a semi-industrial continuous band dryer. Drying Technol., 2008, 26, 1501-1508.

19 Erbay, Z. and Icier, F. Optimization of hot air drying of olive leaves using response surface methodology. J. Food Eng., 2009, 91(4), 533-541.

20 Erbay, Z. and Icier, F. Optimization of drying of olive leaves in a pilot scale heat pump dryer. Drying Technol., 2009, 27(3), 416-427.

21 Menges, H. O. and Ertekin, C. Thin layer drying model for treated and untreated Stanley plums. Energy Convers. Manage., 2006, 47, 2337-2348.

22 Tarhan, S. Selection of chemical and thermal pretreatment combination for plum drying at low and moderate drying air temperatures. J. Food Eng., 2007, 79, 255-260.
23 Anonymous. Dry matter content. In Official methods of analysis of the association of official analytical chemists, Method No. 920.151 (Ed. K. Helrich), 1990, pp. 1298 (A.O.A.C, Inc., Arlington VA, USA).

24 Erbay, Z. and Icier, F. Thin-layer drying behaviors of olive leaves (Olea europaea L.). J. Food Process Eng., 2009, DOI: 10.1111/j.1745-4530.2008.00275.x.

25 Icier, F, Colak, N., Erbay, Z, Hancioglu, E., and Hepbasli, A. A comparative study on exergetic efficiencies of two different drying processes. J. Agric. Sci. (Tarım Makinaları Bilimi Dergisi), 2008, 4, 279-284.

26 Akpinar, E. K., Bicer, Y., and Midilli, A. Modelling and experimental study on drying of apple slices in a convective cyclone dryer. J. Food Process Eng., 2003, 26 $515-541$.

27 Holman, J. P. Analysis of experimental data. In Experimental methods for engineers (Ed. J. P. Holman), 7th edition, 2001, pp. 48-143 (McGraw Hill, Singapore).

28 Bakshi, A. S. and Singh, R. P. Drying characteristics of parboiled rice. In Drying'80 (Ed. A. S. Mujumdar), 1980 (Hemisphere Publishing Company, Washington, DC, USA).

29 Hussain, A., Chen, C. S., Clayton, J. T., and Whitney, L. F. Mathematical simulation of mass and heat transfer in high moisture foods. Trans. ASAE, 1972, 15, 732-736.

30 Hepbasli, A. and Balta, M. T. A study on modeling and performance assessment of a heat pump system utilizing low temperature geothermal resources in buildings. Build. Environ., 2007, 42, 3747-3756.

31 Tsatsaronis, G. Definitions and nomenclature in exergy analysis and exergoeconomics. Energy, 2007, 32, 249-253.

32 Van Gool, W. Energy policy: fairly tales and factualities. In Innovation and technology - strategies and policies (Eds O. D. D. Soares, A. Martins da Cruz, G. Costa Pereira, I. M. R. T. Soares, and A. J. P. S. Reis), 1997, pp. 93-105 (Kluwer Academic Publishers, Dordrecht).

33 Hammond, G. P. and Stapleton, A. J. Exergy analysis of the United Kingdom energy system. Proc. IMechE, Part A: J. Power and Energy, 2001, 215(A2), 141-162. DOI: $10.1243 / 0957650011538424$.

34 Xiang, J. Y., Cali, M., and Santarelli, M. Calculation for physical and chemical exergy of flows in systems elaborating mixed-phase flows and a case study in an IRSOFC plant. Int. J. Energy Res., 2004, 28, 101-115.

35 Nagano, K., Mochida, T., Shimakura, K., Murashita, K., and Takeda, S. Development of thermal-photovoltaic hybrid exterior wallboards incorporating PV cells in and their winter performances. Solar Energy Mater. Solar Cells, 2003, 77, 265-282.

36 Erbay, Z., Icier, F., and Hepbasli, A. Exergetic performance assessment of a pilot scale heat pump belt conveyor drier. Int. J. Energy Res. (in press).

37 Çengel, Y. A. and Boles, M. A. Thermodynamics an engineering approach, 5th edition, 2006 (McGraw-Hill, New York).

38 F-Chart Software. Engineering Equation Solver (EES), Version 8.156D. Madison, WI, USA, 2008.

39 Hepbasli, A., Erbay, Z., Icier, F., Colak, N., and Hancioglu, E. A review of gas engine driven heat pumps (GEHPs) for residential and industrial applications. Renew. Sustain. Energy Rev., 2009, 13(1), 85-99. 
40 Lian, Z., Park, S., Huang, W., Baik, Y., and Yao, Y. Conception of combination of gas-engine-driven heat pump and water-loop heat pump system. Int. J. Refrig., 2005, 28, 810-819.

41 Zhang, R. R., Lu, X. S., Li, S. Z., Lin, W. S., and Gu, A. Z. Analysis on the heating performance of a gas engine driven air to water heat pump based on a steady-state model. Energy Convers. Manage., 2005, 46, 1714-1730.

42 Chua, K. J., Chou, S. K., Ho, J. C., and Hawlader, M. N. A. Heat pump drying: Recent developments and future trends. Drying Technol., 2002, 20(8), 1579-1610.

43 Kudra, T. and Mujumdar, A. S. Advanced drying technologies, 2002 (Marcel Dekker, Inc., New York).

44 Alves-Filho, 0. Combined innovative heat pump drying technologies and new cold extrusion techniques for production of instant foods. Drying Technol., 2002, 20(8), 1541-1557.

45 Pal, U. S., Khan, M. K., and Mohanty, S. N. Heat pump drying of green sweet pepper. Drying Technol., 2008, 26(12), 1584-1590.

46 Mohanraj, M., Chandrasekar, P., and Sreenarayanan, V. V. Performance of a heat pump drier for copra drying. Proc. IMechE, Part A: J. Power and Energy, 2008, 222(A3), 283-287. DOI: 10.1243/09576509JPE548.

47 Lee, K. H. and Kim, O. J. Investigation on drying performance and energy savings of the batch-type heat pump dryer. Drying Technol., 2009, 27(4), 565-573.

\section{APPENDIX}

\section{Notation}

$C \quad$ specific heat $\left(\mathrm{kJ} / \mathrm{kg}^{\circ} \mathrm{C}\right)$

ex specific exergy $(\mathrm{kJ} / \mathrm{kg})$

$\dot{E} \quad$ energy rate $(\mathrm{kW})$

$\dot{E} x \quad$ exergy rate $(\mathrm{kW})$

$f \quad$ exergetic factor (\%)

$F \quad$ function of the independent variables

$\dot{F} \quad$ exergy rate of the fuel $(\mathrm{kW})$

$h \quad$ specific enthalpy $(\mathrm{kJ} / \mathrm{kg})$

I current (A)

$I \dot{P} \quad$ improvement potential rate $(\mathrm{kW})$

$m \quad$ mass $(\mathrm{kg})$

M local moisture content (kg water/kg dry solid)

$M_{\mathrm{e}} \quad$ equilibrium moisture content ( $\mathrm{kg}$ water $/ \mathrm{kg}$ dry solid)

$M_{\mathrm{i}} \quad$ initial moisture content (kg water/kg dry solid)

$M_{\mathrm{t}} \quad$ mean moisture content at time $t(\mathrm{~kg}$ water/kg dry solid)
MR

$P$

$\dot{Q}$

$R$

$s$

$T$

$u$

U $V$
$\dot{W}$

$z$

$\eta$

$\phi$

$\omega$

\section{Subscripts}

$\begin{array}{ll}\text { a } & \text { air } \\ \text { act } & \text { actual } \\ \text { b } & \text { boundary or surface location } \\ \text { comp } & \text { compressor } \\ \text { cond } & \text { condenser } \\ \text { d } & \text { destruction or destroyed } \\ \text { dcab } & \text { drying cabinet } \\ \text { dduct } & \text { drying ducts } \\ \text { elec } & \text { electrical } \\ \text { evap } & \text { evaporator } \\ \text { exp } & \text { expansion valve } \\ \text { HP } & \text { heat pump } \\ \text { in } & \text { inflow } \\ \text { mech } & \text { mechanical } \\ \text { out } & \text { outflow } \\ \text { Overdot } & \text { quantity per unit time } \\ \text { r } & \text { refrigerant } \\ \text { s } & \text { isentropic } \\ \text { v } & \text { vapour } \\ \text { w } & \text { water } \\ \text { 0 } & \text { dead (reference) state } \\ & \end{array}$

Abbreviations

COP coefficient of performance

FBD fluid bed drier

HP heat pump

HPD heat pump drier

HRU heat recovery unit

IP improvement potential

TD tray drier 
Reproduced with permission of the copyright owner. Further reproduction prohibited without permission. 